Aleksandra Živaljevićc ${ }^{1}$

Nikolina Vrcelj ${ }^{2}$

Aleksandra Tošović Stevanović ${ }^{3}$
JEL: 124, 125, 128, L520

DOI:10.5937/industrija43-6983

UDC: 005.94

005.336.3:378.1(497-15)

Original Scientific Paper

\title{
Is Quality of Higher Educational Institutions in Western Balkan Real?
}

\author{
Article history: \\ Received: 19 October 2014 \\ Sent for revision: 2 December 2014 \\ Received in revised form: 31 January 2015 \\ Accepted: 31 January 2015 \\ Available online: 1 April 2015
}

Abstract: The paper presents a survey conducted in November of 2013 in 120 higher education institutions in the Western Balkans Countries, with purpose to determine which models are used for quality improvement in Western Balkans higher educational institutions, and whether critical conditions for continuous quality improvement have been met by applying those models. Data were obtained by using questionnaire which consisted of 24 questions related to 2 previously defined hypotheses. Gathered data were tested with Student's $t$ test to determine if there is a significant difference between the groups of higher educational institutions which use different quality models, as well as between private and public higher educational institutions. Authors argue that the rules imposed by Governments do not provide sufficient incentive for meeting the critical conditions for the continuous quality improvement. Legal framework and mandatory accreditation conducted by government bodies lead higher educational institutions to fulfil the formal requirements, distancing them from the essence of quality management, i.e. from self-criticism and motivation to consistently deliver better results than the previous ones and giving them the illusion of achieving quality through compliance with formal criteria.

Keywords: Process, Higher Education Institution, Quality Management, Standardization, Knowledge Management

\footnotetext{
${ }^{1}$ Megatrend University, Faculty of Business Studies, Belgrade, azivaljevic@megatrend.edu.rs

${ }^{2}$ Megatrend University, Belgrade

${ }^{3}$ Megatrend University, Faculty of Business Studies, Belgrade 
Živaljević A. et al.: Is Quality of Higher Educational Institutions in Western Balkan Real

\section{Da li je kvalitet visokoškolskih ustanova postoji u zemljama Zapadnog Balkana?}

Apstrakt: Rad je zasnovan na istraživanju sprovedenom u novembru 2013. godine u 120 visokoškolskih ustanova Zapadnog Balkana koje je imalo za cilj da pruži saznanja o modelima koje ove ustanove koriste kako bi obezbedile $i$ unapredile kvalitet, kao i da pokaže da li primenjeni modeli dovode do ispunjavanja kritičnih uslova za kontinualno unapređivanje kvaliteta. Podaci su prikupljani struktuiranim upitnicima koji su se sastojali od 24 pitanja vezana za 2 prethodno postavljene hipoteze. Prikupljeni podaci su obrađeni Studentovim t testom kako bi se uvidelo da li postoji značajna razlika između grupa visokoškolskih ustanova koje koriste različite modele, a zatim i između privatnih i državnih ustanova. Autori smatraju da postojeća pravila u pogledu načina organizovanja i funkcionisanja visokoškolskih ustanova ne obezbeđuju dovoljan podsticaj za ispunjavanje kritičnih uslova za kontinualno unapređivanje kvaliteta viskokoškolskih ustanova. Zakonski okvir i obavezna akreditacija, koju sprovode vladine institucije, vode visokoškolske ustanove ka ispunjavanju formalnih zahteva, udaljavajući ih od suštine menadžmenta kvalitetom tj. od samokritičnosti i motivacije da konstantno ostvaruju bolje rezultate od prethodnih, te im stvaraju lažnu sliku o postizanju kvaliteta kroz usaglašavanje sa formalnim kriterijumima.

Ključne reči: Proces, visokoobrazovne ustanove, menadžment kvalitetom, standardizacija, menadžment znanja.

\section{Introduction}

Prerequisite for economic prosperity is knowledge (see: Bercovitz \& Feldman, 2006). It is believed that the educational system, especially higher education $(\mathrm{HE})$, is essential for sustainable growth and global development of a country (Tin, Ismail, Othman, \& Sulaiman, 2012). Yet, there are some researches which show that there is a weak positive correlation between the Global Competitiveness Index of a country and Knowledge Economy Index (see: Krstić \& Stanišić, 2013) indicating that knowledge acquired in educational system does not make impact on country's development. However, higher educational system exists to create knowledge which human resources use for working in economy, culture and all other social spheres, therefore it generates prosperity of the society (Lynch, 2006), and continuously improves the quality of every individual's life. Purpose of HE is to enable development, while knowledge has paramount importance for the growth and development of the industry (Urošević, Cvijanović \& Djordjević, 2008). 
The characteristic of the modern era is the rapid acceleration of development (Bechmann, Berg, Karapetrovic, \& Willborn, 2007). This is due to rapid production of new knowledge and due to growing need for new skills that are necessary for the further development process. The educational system is under the dual pressure of development. On the one hand, educational system is expected to deliver human resources able to engage in socioeconomic processes immediately after graduation, while these socioeconomic processes constantly change and become more demanding under the influence of the development (Komazec, Živaljević \& Trifunović, 2012). Staff, able to contribute to the development using necessary knowledge, is required for development. On the other hand, development constantly generates new knowledge which must be included in the ongoing educational process in a short time in order to prepare graduates to contribute to the same development. This means that the educational system must be flexible manufacturing system, i.e. system that is capable to promptly adapt to changes in the environment and to provide its customers with expected result (Kostal and Velisek, 2010). The flexibility of the system is achieved by constant learning of new requirements of stakeholders and by the ability of the processes within the system to meet emerging requirements using modifications, but with minimal costs, losses and mistakes. Stakeholders' satisfaction (Ballantyne, 1990) and the radical reduction of defect rates and quality costs in the production (Oppermann, Sauer \& Wohlrabe, 2003) or service delivery are the main goals of quality management.

Although students are the most obvious beneficiaries of HE, the economy and society put their demands before $\mathrm{HEl}$, also. These requirements refer to the knowledge which students should have upon graduation (Quinn, Lemay, Larsen \& Johnson, 2009), therefore constant learning of society' requirements, existing and future, is necessary to achieve the educational goals. Requirements for new knowledge affect the existing curriculums and the introduction of new courses, sometimes requiring complete changes of curricula's concepts and the whole new methodologies in knowledge transfer. Furthermore, these changes initiate supplying with new or improved resources which are used in educational process so that educational process becomes able to provide the required level of quality. Necessary quality level of educational system rises along with a continuity of development which supports further progress of development.

The Quality Management Theory recommends PDCA methodology (see: Sokovic, Pavletic \& Pipan, 2010) and Process Approach implementation (see: Petković, Živaljević \& Bagarić, 2005) to achieve the continuous quality improvement. The most widely applied models for quality assurance, such as the ISO 9001 standard, Quality Awards or 'Six Sigma', use PDCA methodology and process approach for its basis (Beckmerhagen, Berg, Karapetrovic \& Willborn, 2003). Process approach sees the organization as a 
network of processes while the quality of one process affects the quality of all related processes by using inputs and outputs exchange. PDCA methodology uses four steps in quality improvement: plan, do, check and act, therefore it is a reliable way to achieve the desired results. It could be said that the critical conditions for continuous quality improvement in HE are:

1. Implementing the process approach through understanding the relationship between all key and critical processes within HEI,

2. Implementing the PDCA methodology in $\mathrm{HEI}$ in order to continuously improve the quality, through:

- Understanding the needs of stakeholders of HEls and appreciating these needs in the future quality planning,

- Assuring key and critical processes to be conducted in planned manner

- Monitoring and measuring the quality of key processes in HEls in order to prevent undesirable outcomes,

- Applying corrective and preventive measures when measured values of quality parameters are out of tolerance range or near to tolerance limit.

3. Improving the knowledge and skills of academic staff in accordance with the development changes i.e. with the requirements of the stakeholders of HEls, by planning and improving knowledge and skills and by measuring effects of improved knowledge and competencies.

Realizing importance of quality improvement in HE for the development, the governments of European countries have started the Bologna process, changes in laws on HE and some of them have established mandatory accreditation of HEls and of their study programs. The Bologna process consists of the series of changes in the educational system which should result in the common European educational system consisting of mutually comparable, compatible and coherent educational subsystems. It should be achieved by harmonizing academic degrees and quality assurance of HEIs (David \& Abreu, 2007). Some authors claim that the Bologna process sets the foundations for quality assurance (Huet, Rafael, Costa, Figueiredo, \& Oliveira, 2011), but there are those authors who argue that the Bologna Declaration is more a matter of form rather than substance (Veiga \& Amaral, 2012) and that the only tangible result of the Bologna university is the decline in the quality of the educational process (Cvijanović, Žižović \& Lazić, 2007)

Accreditation is a process of review that allows HEls or study programs to be recognized and officially certified as those that meet appropriate standards (Harman \& Meek, 2000). Yet, standards are considered as a minimum of requirements for quality achievement (Borders, 1992). 


\section{Development of research framework}

Considering the above, HEls is expected to apply PDCA methodology and process approach if they strive to quality and understand their role in the rapid development. Identification of all key and critical processes is crucial for a proper implementation of process approach. Key processes create and deliver value to the society while critical processes support functioning of key processes. Two key processes in HEls are producing two types of knowledge. One type of knowledge is being created in the educational process. It is a knowledge designed for students to make them suitable for involvement in working processes in order to contribute to the development. The second type of knowledge, new knowledge, is being created in the scientific research process. New knowledge should be implemented in the social, economic and business trends, and also included in educational process in a short period of time, so that students would not lag behind developmental changes. Academic staff must adopt new knowledge (Carlucci, Marr \& Schiuma, 2004), i.e. increase competence in order to involve new knowledge in the educational process. Adopting new knowledge should not be spontaneous and voluntary, but it rather be handled by institutions as a critical process (see: Živaljević, Mitrović \& Petković, 2013), i.e. it should be planned, done, checked and improved. Also, the process of publishing books, manuscripts and proceedings as well as the processes of student services are critical as their malfunction can jeopardize quality of the educational process. Poor quality of the publishing process can reduce the value of new knowledge which has been created in the scientific research.

PDCA methodology must be applied on each identified key and critical process to support continuous quality improvement. It means that each process has to be planned, done, checked and improved. Planning should be based on stakeholders' requirements in order to achieve planned objectives by realization. Both key processes: education and scientific research, as well as their results - the students' knowledge and new knowledge, have stakeholders which generate requirements. Therefore, essential first step in planning is to identify all stakeholders and their requirements so that educational process and scientific research are directed correctly. Students, scientific community, industries and society are suggested in most papers as stakeholders of HE (see: Khanifar, Esfidani, Nazari \& Naderi, 2013; Karapetrovic, Rajamani \& Willborn, 1998). Results of HE should provide development which will happen in the future, therefore planning must consider the future needs of society, too.

Quality can be assured in realization by using different methods, but it is important that realization isn't left to chance. As results of key processes in $\mathrm{HE}$ occur usually after more than four, it is enough time for reacting if key 
processes, at some stage, create lower quality than planned. Mechanism for identification of poor quality is based on monitoring and measuring predefined quality parameters of key and critical processes and on comparing obtained values with the pre-defined target values.

Some studies, predominantly done for healthcare facilities, reported that notfor-profit institutions delivered higher quality than for-profit institutions (Comondore, et al. 2009). Those studies were mostly based on services' results and not on those analyzed conditions critical for continuous quality improvement. Also, there are studies on accreditation vs. certification which use criteria of quality and safety to find out the differences between quality models applied in institutions (Shaw, Groene, Mora \& Sunol, 2010), but there is no study which answers the question on what influences meeting the critical conditions for continuous quality improvement more in HE; ownership or applied model for quality assurance.

\section{Research method}

The aim of the research was to learn if ownership and/or applied model for quality assurance affect fulfilling of critical conditions for continuous quality improvement in HEls. Western Balkans countries participate in the European higher educational area. In the past twenty years, Western Balkans educational area has been reforming through abandonment of "Humboldt" model (see: Dobbins \& Knill, 2009), which was dominant for almost fifty years, and through the adoption of the market-oriented model (Dobbins, Knill. \& Vögtle, 2011) with some elements of state-control model (see: Mok, 2003). One of the main mechanisms for quality assurance of HEls in most countries of the Western Balkans is mandatory accreditation while some institutions also apply other models for quality assurance, which makes this region a good area for conducting a research. Research hypotheses were:

"H1: There is no significant difference between private and public HEls in fulfilling critical conditions for continuous quality improvement."

"H2: There is no significant difference between HEls which apply only accreditation model and HEls which apply other models for quality assurance besides accreditation model in fulfilling critical conditions for continuous quality improvement."

In November 2013 the authors have conducted a survey of 120 Western Balkans HEls by interviewing faculties using questionnaire that consisted of 24 questions related to critical conditions for continuous quality improvement. Western Balkans population speaks different languages; therefore questionnaire was designed in English also all subjects can understand it. To 
ensure that answers will be provided by a competent person and that research results are current and accurate, the questionnaire was sent to the management of each $\mathrm{HEl}$.

All collected data were divided into two groups according to the criteria of ownership (private and public), and then t-test was applied to learn whether there was a significant difference between those two groups, i.e. whether ownership influenced the way of quality assurance in HEls. Then, entire sample was reassembled and divided again into two groups according to the criteria of models used by $\mathrm{HEI}$ to assure quality. First group consisted of institutions which used only mandatory accreditation model, while the second group consisted of institutions which applied other models together with mandatory accreditation model. Confidence interval for t-test was $95 \%$, i.e. $\alpha=0.05$ in both cases.

\section{Characteristic of the educational systems of Western Balkan Countries}

Twenty years ago, all HEls in the region were public, when the first private HEI was established in the Republic of Serbia (in 1993). In the decade that followed, the mass establishment of private HEls in this region has begun, and states have had no control over their functioning. However, with joining the Bologna process (in 2003), quality of HE area has obtained significance in the Western Balkans.

Table 1. Characteristic of Western Balkan higher educational systems

\begin{tabular}{|c|c|c|c|c|c|c|c|c|c|c|}
\hline & \multicolumn{2}{|c|}{ No. ofHت } & \multicolumn{2}{|c|}{$\begin{array}{c}\text { PrivateH日in } \\
\%\end{array}$} & \multicolumn{2}{|c|}{ No. of students } & \multicolumn{2}{|c|}{$\begin{array}{c}\text { Imvestmentin } \\
\text { HE\%GDP }\end{array}$} & \multicolumn{2}{|c|}{ GDPin\$ } \\
\hline & $03 / 04$ & $12 / 13$ & $03 / 04$ & 1213 & $03 / 04$ & $12 / 3$ & 2003. & 2013 & 2013. & 2003. \\
\hline Albania & 12 & 64 & 0 & 45,25 & 53014 & 162875 & 3 & 5,3 & 12.903 .854 .876 & 5.652325 .082 \\
\hline Croatia & 102 & 120 & 0 & 25,83 & 120822 & 157289 & 4 & $\mathrm{Na}$ & 57.538 .524 .789 & 34.143 .409 .062 \\
\hline $\begin{array}{l}\text { Bosniaand } \\
\text { Herzegovina }\end{array}$ & 65 & 106 & 0 & 31,13 & 54425 & 72460 & $\mathrm{Na}$ & $\mathrm{Na}$ & 17.827.710.271 & 8.370.020.196 \\
\hline Macedonia & 30 & 123 & 0 & 77,78 & 46637 & 56906 & 1,36 & 1,17 & 10.220 .781 .069 & 4.756 .221629 \\
\hline Montenegro & 15 & 43 & 0 & 46,52 & 9759 & 22279 & $\mathrm{Na}$ & 0,42 & 4.427 .771 .436 & 4.373 .170 .812 \\
\hline Serbia & 201 & 202 & $\mathrm{Na}$ & 34,44 & 203909 & 193255 & 1,3 & 1,20 & 42.520 .511 .655 & 19.550 .781 .969 \\
\hline Total & 425 & 645 & $\mathrm{Na}$ & 43,49 & 488566 & 665064 & $\mathrm{Na}$ & $\mathrm{Na}$ & 145.439 .154 .096 & 76.845 .928 .750 \\
\hline
\end{tabular}

Source: data of World Bank, data of research results presented on HERDATA webpage (Country Reports fore each Western Balkan Country separate: Branković, 2013; Branković and Branković, 2013; Šćukanec, 2013; Vujačić et al., 2013; Vujačić et al., 2013; Xhaferri and Branković, 2013), KAPK reports on self-evaluation (Pekić Quarrie et al., 2013) and authors" data processing

Countries in the region have changed their Laws on Education, designed Standards for the Accreditation of HEls and introduced mandatory 
accreditation, all striving to stimulate quality improvement of HEls and to establish control over the educational process. Therefore, the year of 2003 can be considered as the year of the beginning of transition of $\mathrm{HE}$ in the Western Balkans. Table 1 shows characteristics of the Western Balkans HE in the year of the transition beginning and in the year of survey conducted for hypothesis testing.

\section{Research results and analysis}

All sampled HEls are accredited. Earliest accreditation was conducted 7 years ago and the latest accreditation is less than 2 years old. Twelve private and two public HEls of a sample are using, besides standards for accreditation, the additional model for quality assurance which is in all cases QMS model, recommended by ISO 9001 standard. Structure of the sample according to ownership and applied model in HEls is given in Table 2, while Figure 1 shows each country's share in the sample. Table 3 shows results of the survey regarding the process approach implementation.

Table 2. Structure of the research sample

\begin{tabular}{|c|c|c|}
\hline Type of model for quality & $\begin{array}{c}\text { HEI which apply only } \\
\text { accreditation standards } \\
{[\%]}\end{array}$ & $\begin{array}{c}\text { HEI which apply QMS together } \\
\text { with accreditation standards [\%] }\end{array}$ \\
\hline Pype of ownership & 32,5 & 10,00 \\
\hline Public & 55,83 & 1,67 \\
\hline
\end{tabular}

Source: authors" data processing

Figure 1. Country's sample share

Percent of the

sample [\%]

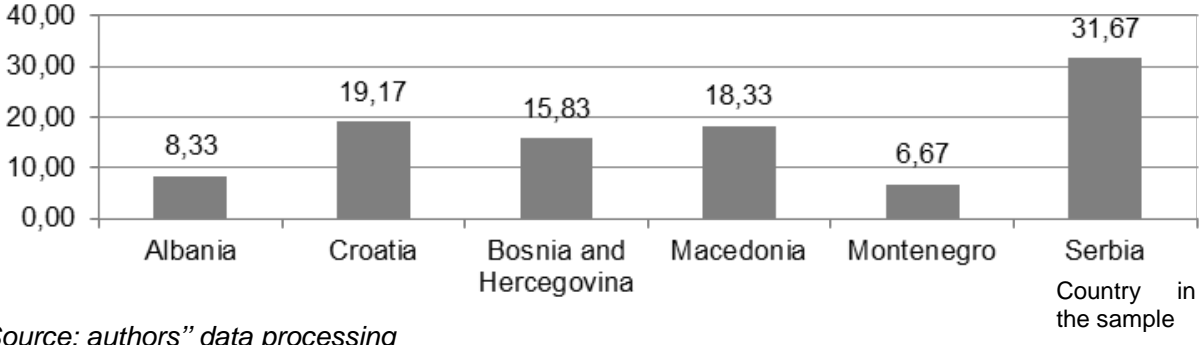

Source: authors" data processing 
Živaljević A. et al.: Is Quality of Higher Educational Institutions in Western Balkan Real

Table 3. Characteristics of process approach implementation within the groups of sample

\begin{tabular}{|c|c|c|c|c|}
\hline & \multicolumn{2}{|c|}{$\begin{array}{l}\text { according to } \\
\text { ownership }\end{array}$} & \multicolumn{2}{|c|}{ according to model type } \\
\hline & $\begin{array}{c}\text { Private } \\
\text { HEl } \\
{[\%]}\end{array}$ & $\begin{array}{c}\text { Public } \\
\text { HEl } \\
{[\%]}\end{array}$ & $\begin{array}{l}\text { HEl which apply } \\
\text { only mandatory } \\
\text { accreditation [\%] }\end{array}$ & $\begin{array}{c}\text { HEl which apply ISO } \\
9001 \text { with mandatory } \\
\text { accreditation [\%] }\end{array}$ \\
\hline Educational process & 100,00 & 100,00 & 100,00 & 100,00 \\
\hline Process of scientific research & 100,00 & 100,00 & 100,00 & 100,00 \\
\hline Process of student's service & 100,00 & 0,00 & 71,70 & 85,71 \\
\hline Process of publishing & 23,86 & 12,50 & 12,26 & 85,71 \\
\hline $\begin{array}{r}\text { Process of knowledge } \\
\text { improvement of academic stuff }\end{array}$ & 100,00 & 100,00 & 100,00 & 100,00 \\
\hline $\begin{array}{l}\text { Relations between key and critical } \\
\text { processes are identified }\end{array}$ & 13,64 & 6,25 & 0,00 & 100,00 \\
\hline $\begin{array}{r}d f=10, \alpha=0,05 \\
\text { two tailed test } t_{(10,0,05)}= \pm 2,2281\end{array}$ & \multicolumn{2}{|c|}{$t_{1}=0,841701$} & \multicolumn{2}{|c|}{$t_{2}=-1,8848$} \\
\hline No. of HEl in the group of sample & 51 & 69 & 106 & 14 \\
\hline
\end{tabular}

Source: authors" data processing

As for two-tailed statistics $t_{(10 ; 0,05)}= \pm 2,2281$, the research results show that there is no significant difference between any of groups while $\mathrm{t}_{\text {left(10;0,05) }}<\mathrm{t} 1<\mathrm{t}_{\text {right }(10 ; 0,05)}$ and $\mathrm{t}_{\text {left(10;0,05) }}<\mathrm{t} 2<\mathrm{t}_{\text {rig(10;0,05) }}$. It can be concluded that neither ownership nor type of model affect fulfilling the first critical condition in HE.

Table 4. Stakeholders which were recognized in planning process by each group of sample

\begin{tabular}{|c|c|c|c|c|}
\hline & \multicolumn{4}{|c|}{ Groups } \\
\hline & \multicolumn{2}{|c|}{ according to ownership } & \multicolumn{2}{|c|}{ according to model type } \\
\hline & $\begin{array}{c}\text { Private } \\
\text { HEI } \\
{[\%]}\end{array}$ & $\begin{array}{l}\text { Public HEI } \\
{[\%]}\end{array}$ & $\begin{array}{c}\text { HEI which } \\
\text { apply only } \\
\text { mandatory } \\
\text { accreditation } \\
{[\%]}\end{array}$ & $\begin{array}{l}\text { HEI which apply } \\
\text { ISO } 9001 \text { with } \\
\text { mandatory } \\
\text { accreditation [\%] }\end{array}$ \\
\hline Students & 100,00 & 100,00 & 100,00 & 100,00 \\
\hline Companies and institutions & 72,73 & 65,63 & 66,98 & 100,00 \\
\hline Existing society & 95,45 & 100,00 & 100,00 & 71,43 \\
\hline Future society & 1,14 & 100,00 & 28,30 & 21,43 \\
\hline Scientific community & 100,00 & 90,63 & 97,17 & 100,00 \\
\hline $\begin{array}{r}d f=8, \quad \alpha=0,05 \\
\text { two tailed test } t_{(8 ; 0,05)}= \pm 2,3060\end{array}$ & \multicolumn{2}{|c|}{$t_{1}=-1,22866$} & \multicolumn{2}{|c|}{$\mathrm{t}_{2}=0,00551$} \\
\hline No. of HEl in the group of sample & 51 & 69 & 106 & 14 \\
\hline
\end{tabular}

Source: authors" data processing 
Understanding the needs of stakeholders of HEls and appreciating these needs in the future quality planning is second critical condition. Tables 4 and 5 show which stakeholders HEI recognize and what methods for learning their needs $\mathrm{HEl}$ use in each group of sample.

While two-tailed statistics $t_{(8 ; 0,05)}$ is $\pm 2,3060, \quad t_{\text {left( }(8 ; 0,05)}<t 1<t_{\text {right }(8 ; 0,05)}$ and $\mathrm{t}_{\text {left( }(8 ; 0,05)}<\mathrm{t} 2<\mathrm{t}_{\text {rig( }(8 ; 0,05)}$, it can be concluded that there is no significant difference between any of groups, i.e. neither ownership nor type of model which HEI apply affect recognizing stakeholders in planning processes of HEls. However, private institutions pay the least attention on future society of all sample groups, meaning that they could be the least conformed with development needs of society.

Table 5. Ways each group of sample use to anticipate stakeholders' requirements

\begin{tabular}{|c|c|c|c|c|}
\hline & \multicolumn{4}{|c|}{ Groups } \\
\hline & \multicolumn{2}{|c|}{$\begin{array}{l}\text { according to } \\
\text { ownership }\end{array}$} & \multicolumn{2}{|c|}{ according to model type } \\
\hline & $\begin{array}{l}\text { Private } \\
\text { HEI } \\
{[\%]}\end{array}$ & $\begin{array}{l}\text { Public } \\
\text { HEI } \\
{[\%]}\end{array}$ & $\begin{array}{l}\text { HEI which apply } \\
\text { only mandatory } \\
\text { accreditation [\%] }\end{array}$ & $\begin{array}{l}\text { HEI which apply } \\
\text { ISO } 9001 \text { with } \\
\text { mandatory } \\
\text { accreditation [\%] }\end{array}$ \\
\hline Research academic staff's needs & 0,00 & 3,13 & 0,00 & 7,14 \\
\hline Survey of academic staff's satisfaction & 0,00 & 0,00 & 0,00 & 0,00 \\
\hline Survey on students' satisfaction & 100,00 & 100,00 & 100,00 & 100,00 \\
\hline Research the students' needs & 21,59 & 6,25 & 6,60 & 100,00 \\
\hline Talking to students on tribunes & 23,86 & 3,13 & 14,15 & 50,00 \\
\hline Survey on existing industry's needs & 80,68 & 3,13 & 59,43 & 64,29 \\
\hline $\begin{array}{r}\text { Survey of industry's satisfaction with } \\
\text { hired graduates }\end{array}$ & 6,82 & 0,00 & 0,00 & 42,86 \\
\hline $\begin{array}{r}\text { Analyzing trends in society in the next } \\
5 \text { years }\end{array}$ & 5,68 & 6,25 & 0,00 & 50,00 \\
\hline $\begin{array}{r}\text { Analyzing trends in society in the next } \\
10 \text { years }\end{array}$ & 3,41 & 0,00 & 0,00 & 21,43 \\
\hline $\begin{array}{r}\text { Analyzing trends in society in the next } \\
20 \text { years }\end{array}$ & 0,00 & 0,00 & 0,00 & 0,00 \\
\hline $\begin{array}{l}\text { Analyzing curricula of leading faculties } \\
\text { in similar scientific field }\end{array}$ & 18,18 & 18,75 & 12,26 & 64,29 \\
\hline $\begin{array}{r}\text { Research firms' needs for future } \\
\text { knowledge of graduates }\end{array}$ & 15,91 & 6,25 & 1,89 & 100,00 \\
\hline Research alumni' needs & 17,05 & 15,63 & 9,43 & 71,43 \\
\hline $\begin{array}{r}\text { Scientific agreements with firms or } \\
\text { Ministry of Science }\end{array}$ & 7,95 & 100,00 & 33,02 & 28,57 \\
\hline $\begin{array}{r}d f=26, \alpha=0,05 \\
\text { two tailed test } t_{(26 ; 0,05)}= \pm 2,2055\end{array}$ & \multicolumn{2}{|c|}{$\mathrm{t}_{1}=0,88273$} & \multicolumn{2}{|c|}{$\mathrm{t}_{2}=-10,6366$} \\
\hline No. of HEl in the group of sample & 51 & 69 & 106 & 14 \\
\hline
\end{tabular}

Source: authors" data processing 
There is significant difference in methods for anticipating stakeholders' needs between HEls which apply only mandatory accreditation model and those that apply QMS model besides mandatory accreditation (two-tailed statistics is $t_{(26 ; 0,05)}= \pm 2,2055$ and $\left.t_{t \text { teft(26;0,05) }}>t 2\right)$. It means that QMS model affects the increase in the number of methods for anticipating stakeholders' needs, thereby increasing the opportunities for learning all requirements, existing and those that will occur in the future. As $t_{\text {left( }(26 ; 0,05)}<t 1<t_{\text {rig(26;0,05), }}$, the difference between private and public HEls is not significant, i.e. ownership does not impact methods for anticipating stakeholders' needs.

Assuring processes to run in planned manner is important for second step of PDCA methodology in order to assure results. Ways of assuring process realization for each group of sample are given in Table 6 .

Table 6. Ways of assuring process realization to conduct in planned manner within the groups of sample

\begin{tabular}{|c|c|c|c|c|}
\hline & \multicolumn{4}{|c|}{ Groups } \\
\hline & \multicolumn{2}{|c|}{ according to ownership } & \multicolumn{2}{|c|}{ according to model type } \\
\hline & $\begin{array}{c}\text { Private } \\
\text { HEI } \\
{[\%]}\end{array}$ & $\begin{array}{c}\text { Public } \\
\text { HEI } \\
{[\%]}\end{array}$ & $\begin{array}{c}\text { HEI which apply } \\
\text { only mandatory } \\
\text { accreditation } \\
{[\%]}\end{array}$ & $\begin{array}{l}\text { HEI which apply ISO } \\
9001 \text { with mandatory } \\
\text { accreditation [\%] }\end{array}$ \\
\hline $\begin{array}{r}\text { Procedures, instruction and } \\
\text { records }\end{array}$ & 13,64 & 6,25 & 0,00 & 100,00 \\
\hline Using software & 3,41 & 6,25 & 0,00 & 35,71 \\
\hline $\begin{array}{r}\text { Monitoring and measuring } \\
\text { quality parameters }\end{array}$ & 13,64 & 6,25 & 0,00 & 100,00 \\
\hline Internal audits & 13,64 & 6,25 & 0,00 & 100,00 \\
\hline Quality tools & 7,95 & 0,00 & 0,00 & 50,00 \\
\hline Peer review & 13,64 & 6,25 & 0,00 & 100,00 \\
\hline Statistical methods & 92,05 & 81,25 & 87,74 & 100,00 \\
\hline Self-assessment & 92,05 & 100,00 & 93,40 & 100,00 \\
\hline Law on HE & 100,00 & 100,00 & 100,00 & 100,00 \\
\hline $\begin{array}{l}\text { External audits conducted by } \\
\text { Accreditat.Commission }\end{array}$ & 100,00 & 100,00 & 100,00 & 100,00 \\
\hline $\begin{array}{r}\mathrm{df}=18, \alpha=0,05 \\
\text { two tailed test } \mathrm{t}_{(18 ; 0,05)}= \\
\pm 2,1009\end{array}$ & \multicolumn{2}{|c|}{$t_{1}=0,497385$} & \multicolumn{2}{|c|}{$\mathrm{t}_{2}=-7,83369$} \\
\hline No. of HEl in the group of sample & 51 & 69 & 106 & 14 \\
\hline
\end{tabular}

Source: authors" data processing

Two-tailed t test shows that there was significant difference in ways of assuring process realization between HEls which apply only mandatory accreditation model and those that apply QMS model besides mandatory accreditation, while such difference did not exist between private and public institutions $\left(\mathrm{t}_{(18 ; 0,05)}= \pm 2,1009, \mathrm{t}_{1}=0,497385\right.$ and $\left.\mathrm{t}_{2}=-7,83369\right)$. It can be further 
Živaljević A. et al.: Is Quality of Higher Educational Institutions in Western Balkan Real

concluded that QMS model implementation increases the probability of realizing planned outcomes of the processes. It hereby reduces the number of poor process' results and thus reduces the cost of corrections and corrective measures, while it affects reducing the difference between required and achieved quality.

Table 7. Quality parameters of key and critical processes which each group monitor and measure

\begin{tabular}{|c|c|c|c|c|}
\hline \multirow[b]{3}{*}{ Average score of students' satisfaction } & \multicolumn{2}{|c|}{$\begin{array}{l}\text { according to } \\
\text { ownership }\end{array}$} & \multicolumn{2}{|c|}{ according to model type } \\
\hline & $\begin{array}{c}\text { Private } \\
\text { HEI } \\
{[\%]}\end{array}$ & $\begin{array}{c}\text { Public } \\
\text { HEI } \\
{[\%]}\end{array}$ & $\begin{array}{l}\text { HEI which apply } \\
\text { only mandatory } \\
\text { accreditation [\%] }\end{array}$ & $\begin{array}{l}\text { HEI which apply } \\
\text { ISO } 9001 \text { with } \\
\text { mandatory } \\
\text { accreditation [\%] }\end{array}$ \\
\hline & 100,00 & 100,00 & 100,00 & 100,00 \\
\hline Percentage of realized classes & 4,55 & 0,00 & 0,00 & 28,57 \\
\hline Perc. of stud. which passed the exam & 100,00 & 100,00 & 100,00 & 100,00 \\
\hline $\begin{array}{l}\text { Percentage of realization of scientific } \\
\text { research projects in relation to the plan }\end{array}$ & 6,82 & 71,88 & 19,81 & 57,14 \\
\hline $\begin{array}{l}\text { No.of failures in the organization or } \\
\text { implementation of scientific conferences }\end{array}$ & 2,27 & 0,00 & 0,00 & 14,29 \\
\hline $\begin{array}{l}\text { No of scientific papers in respected } \\
\text { acad. journals per acad.employee }\end{array}$ & 100,00 & 100,00 & 100,00 & 100,00 \\
\hline $\begin{array}{l}\text { No. of founded complaints on the } \\
\text { performance of student senvice }\end{array}$ & 13,64 & 6,25 & 0,00 & 100,00 \\
\hline $\begin{array}{r}\text { Average score of students' satisfaction } \\
\text { with student senvice }\end{array}$ & 13,64 & 0,00 & 0,00 & 85,71 \\
\hline $\begin{array}{l}\text { The average time student spends } \\
\text { waiting on document or information }\end{array}$ & 5,68 & 0,00 & 0,00 & 35,71 \\
\hline $\begin{array}{l}\text { Percentage of published books and } \\
\text { proceedings compared to planned }\end{array}$ & 6,82 & 0,00 & 0,00 & 42,86 \\
\hline $\begin{array}{l}\text { Percentage of nonconformities in } \\
\text { published books and proceedings }\end{array}$ & 3,41 & 0,00 & 0,00 & 21,43 \\
\hline Percent.of students abandon studying & 70,45 & 100,00 & 81,13 & 57,14 \\
\hline Percent.of students graduate in time & 60,23 & 100,00 & 72,64 & 57,14 \\
\hline Perc. of students get a job in profession & 23,86 & 6,25 & 16,98 & 35,71 \\
\hline $\begin{array}{r}\begin{array}{r}\text { Students av.waiting time on a job in } \\
\text { profession }\end{array} \\
\end{array}$ & 23,86 & 0,00 & 15,09 & 35,71 \\
\hline $\begin{array}{l}\text { Percent.of graduates which continue } \\
\text { postgraduate studies at same faculty }\end{array}$ & 25,00 & 12,50 & 16,98 & 57,14 \\
\hline $\begin{array}{l}\text { Percent.of graduates that continue } \\
\text { postgraduate studies in country }\end{array}$ & 0,00 & 0,00 & 0,00 & 0,00 \\
\hline $\begin{array}{r}\text { Percent.of graduates that continue } \\
\text { postgraduate studies abroad }\end{array}$ & 25,00 & 12,50 & 16,98 & 57,14 \\
\hline $\begin{array}{r}d f=34, \alpha=0,05 \\
\text { two tailed test } t_{(34 ; 0,05)}= \pm 2,0322\end{array}$ & \multicolumn{2}{|c|}{$t_{1}=-0,51167$} & \multicolumn{2}{|c|}{$\mathrm{t}_{2}=-10,797$} \\
\hline No. of HEl in the group of sample & 51 & 69 & 106 & 14 \\
\hline
\end{tabular}

Source: authors" data processing 
Undesirable deviations from planned results are detected by monitoring and measuring quality parameters of key and critical process, enabling reaction in time and prevention of poor quality to cause larger impact on society and its development. Table 7 shows quality parameters of key and critical processes monitored and measured by each sampled group.

Two-tailed $t$ test showed that there was a significant difference in monitoring and measuring quality parameters between HEls which apply only mandatory accreditation model and those that apply QMS model besides mandatory accreditation, while $t_{(34 ; 0,05)}= \pm 2,0322$ and $t_{2}=-10,797$. Such difference did not exist between private and public institutions as $t_{1}=-0,51167$ is still in confidence interval. The conclusion can be imposed that the QMS model enhances the ability to detect errors in time, which improves control of key and critical process.

If measured values of quality parameters show deviations from plan, corrective measures should be applied. Measured values can indicate that process is not stable or that there is possibility for nonconformities in the future which should cause introduction of preventive measures. Characteristics of each group of sample according to preventive and corrective measures are given in Table 8.

Table 8. Prevention and correction of unwanted results of key and critical processes in each group of sample

\begin{tabular}{|c|c|c|c|c|}
\hline & \multicolumn{3}{|c|}{ Groups } & \\
\hline & \multicolumn{2}{|c|}{ according to ownership } & \multicolumn{2}{|c|}{ according to model type } \\
\hline & $\begin{array}{l}\text { Private } \\
\text { HEl } \\
{[\%]}\end{array}$ & $\begin{array}{l}\text { Public } \\
\text { HEl } \\
{[\%]}\end{array}$ & $\begin{array}{c}\text { HEI which } \\
\text { apply only } \\
\text { mandatory } \\
\text { accreditation } \\
{[\%]}\end{array}$ & $\begin{array}{l}\text { HEI which apply } \\
\text { ISO } 9001 \text { with } \\
\text { mandatory } \\
\text { accreditation [\%] }\end{array}$ \\
\hline $\begin{array}{r}\text { Preventive measures derived from } \\
\text { quality parameters' measured } \\
\text { values }\end{array}$ & 21,59 & 12,50 & 8,49 & 100,00 \\
\hline $\begin{array}{r}\text { Corrective measures derived } \\
\text { from quality parameters' } \\
\text { measured values }\end{array}$ & 13,64 & 6,25 & 0,00 & 100,00 \\
\hline $\begin{array}{r}d f=2, \alpha=0,05 \\
\text { two tailed test } t_{(2 ; 0,05)}= \pm 4,3027\end{array}$ & \multicolumn{2}{|c|}{$t_{1}=0,364211$} & \multicolumn{2}{|c|}{$t_{2}=-5,04358$} \\
\hline No. of HEI in the group of sample & 51 & 69 & 106 & 14 \\
\hline
\end{tabular}

Source: authors" data processing

There is significant difference between HEls which apply only mandatory accreditation model and those that apply QMS model in corrective and preventive measures, while $t_{(2 ; 0,05)}= \pm 4,3027$ and $t_{2}=-5,04358$. Such difference does not exist between private and public institutions as $t_{1}$ is $-0,51167$. It can 
be concluded that the QMS model decreases the chances of major damage occurrence which is consequence of possible poor quality of HEls.

Given that there is no difference in the planning, doing, checking and acting between public and private HEls, ownership does not affect meeting the critical conditions. When it comes to HEls that use only the accreditation model, and those that use also QMS model, the difference does not exists only in recognizing the customers whose requirements should be learned in order to set them as a basis for the planning process. However, there is a significant difference between them in the number of methods they use to learn customers' requirements, which further indicates the existence of differences in the first stage of the PDCA methodology, i.e. planning phase.

In all other phases of PDCA methodology: do, check and act, the difference between HEls that use only accreditation model and those that also apply QMS model, is obvious. Therefore, it can be concluded that model which HEls apply affects PDCA implementation, i.e. affects meeting the second critical condition.

Third critical condition for continuous quality improvement in HE is improving the knowledge and skills of academic staff in accordance with the development changes. Table 9 shows the extent to which the planning, implementation and measurement of the effects of improved knowledge is represented in each group of sample.

Table 9. Characteristics of managing knowledge and skills improvement of academic staff in each group of sample

\begin{tabular}{|c|c|c|c|c|}
\hline \multicolumn{5}{|c|}{ Groups } \\
\hline \multirow[b]{3}{*}{$\begin{array}{r}\text { Planning academic staff's knowledge } \\
\text { and skills improvements }\end{array}$} & \multicolumn{2}{|c|}{$\begin{array}{l}\text { according to } \\
\text { ownership }\end{array}$} & \multicolumn{2}{|c|}{ according to model type } \\
\hline & $\begin{array}{l}\text { Private } \\
\text { HEI } \\
{[\%]}\end{array}$ & $\begin{array}{l}\text { Public } \\
\text { HEl } \\
{[\%]}\end{array}$ & $\begin{array}{l}\text { HEI which apply } \\
\text { only mandatory } \\
\text { accreditation [\%] }\end{array}$ & $\begin{array}{c}\text { HEI which } \\
\text { apply ISO } 9001 \\
\text { with mandatory } \\
\text { accreditation } \\
{[\%]}\end{array}$ \\
\hline & 100,00 & 100,00 & 100,00 & 100,00 \\
\hline $\begin{array}{l}\text { Realizing planned academic staff's } \\
\text { knowledge and skills improvements }\end{array}$ & 100,00 & 100,00 & 100,00 & 100,00 \\
\hline $\begin{array}{r}\text { Monitoring and measuring effects } \\
\text { of academic staff's knowledge and } \\
\text { skills improvements }\end{array}$ & 13,64 & 6,25 & 0,00 & 100,00 \\
\hline $\begin{array}{r}d f=4, \alpha=0,05 \\
\text { two tailed test } t_{(4 ; 0,05)}=4,3027\end{array}$ & \multicolumn{2}{|c|}{$t_{1}=0,029924$} & \multicolumn{2}{|c|}{$t_{2}=-0,5164$} \\
\hline No. of $\mathrm{HEl}$ in the group of sample & 51 & 69 & 106 & 14 \\
\hline
\end{tabular}

Source: authors" data processing 
Two-tailed t test showed that there is no significant difference in knowledge and skills improvement of academic staff between any of the groups of sample while $t_{(4 ; 0,05)}=4,3027, t_{1}=0,029924$ and $t_{2}=-0,5164$. However, monitoring and measuring effects of quality improvements of knowledge and skills of academic staff is done in all HEls which apply ISO 9001 model besides mandatory accreditation, but in neither one institution which apply only mandatory accreditation model. It means that accreditation model does not enable proper reaction in case of insufficient improvement of competences which can lead to quality degradations of the educational and scientific research processes in the future. The results obtained using the ttest are summarized and presented in Table 10.

Table 10. Summary of results of testing the differences in fulfilling critical conditions for continuous quality improvement

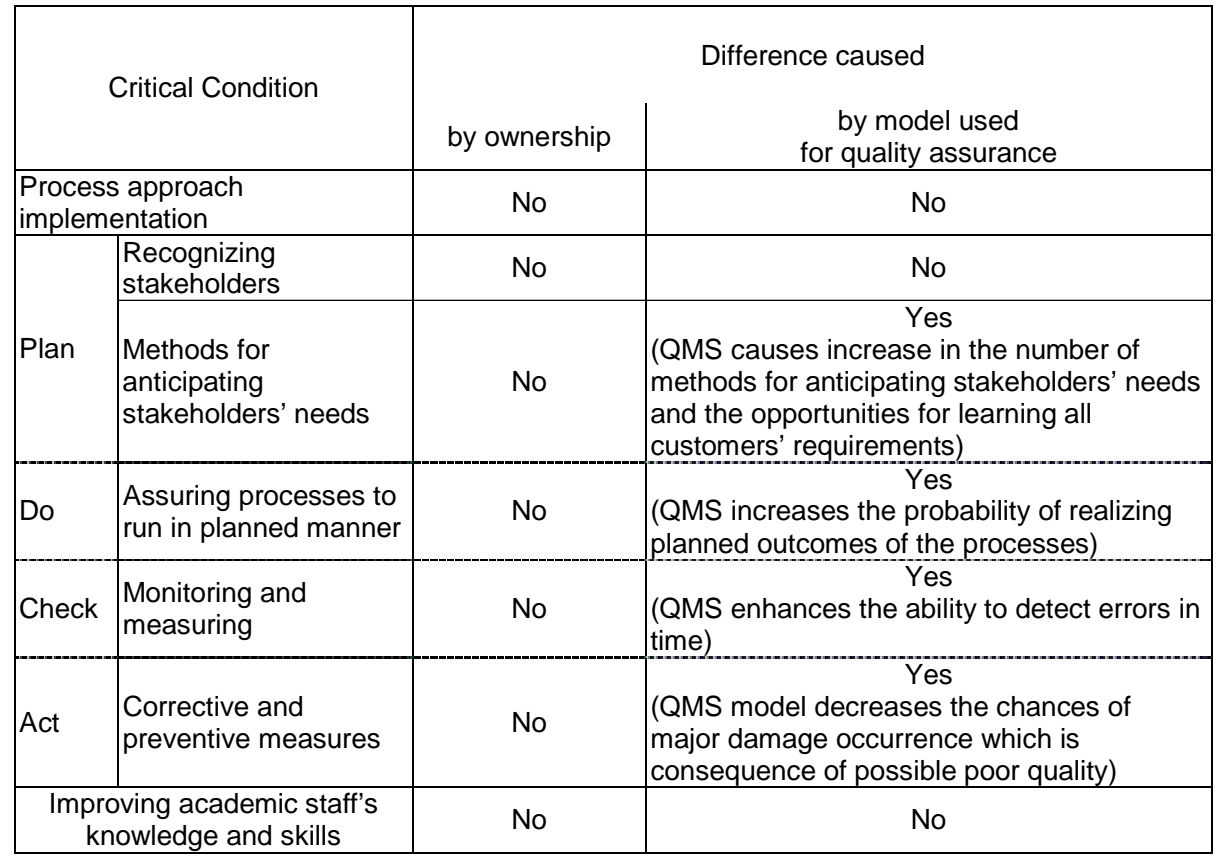

Source: authors" data processing

Hypothesis $\mathrm{H} 1$ is completely proven to be true, which means that ownership structure does not affect the fulfilment of critical conditions and that public and private HEls are equal in following the recommendations of Quality Management theory that are defined for continuous quality improvement. Hypothesis $\mathrm{H} 2$ is partially proven to be true, but there is a difference with respect to the application of PDCA methodology for those HE institutions that 
implement QMS model in addition to the accreditation model. Research has shown that QMS model:

- causes increase in the number of methods for anticipating stakeholders' needs, thereby increase in the opportunities for learning all customers' requirements,

- enables increase of probability for delivered outcomes of the processes to be equal with planned ones,

- enhances the ability to detect errors in time and to react before those errors become visible to customers and society,

- decreases the chances of major damage occurrence which is consequence of possible poor quality

\section{Conclusion}

The results showed that difference in realization, assurance and improvement of quality is not caused by ownership structure, but by model which institution applies. Further analysis leads to conclusion that a decision on the implementation of additional models, not required by law, is based on the management's understanding that high quality of $\mathrm{HE}$ services is essential mission of such institutions while it contributes to the development of the whole society. This attitude of management leads to the so-called 'management's commitment to quality', which is a prerequisite for quality achievement (Gotzamani, 2004). Commitment to quality initiated the identification of elements that create quality, i.e. key and critical processes and establishment of control over them. To improve quality, committed HEIs defined quality parameters of the processes, continuously monitor and measure them, analyse measured values, which provide an objective basis for conclusions about the existing quality trend in these institutions.

In the case of institutions that rely only on respecting the Law and mandatory accreditation, mechanisms for continuous quality improvement are not fully applied. Discussion can be started about the effectiveness of financial resources spent for harmonizing institutions with requirements of accreditation standard, since the achievement of the main objective, reflected in the achievement of projected levels of quality of higher educational services and the creation of developmental potential, is uncertain.

The general conclusion of the research is that HEls which do not apply additional models for quality improvement, deliver inadequate knowledge for economic development. Therefore, the necessity is to increase awareness on the importance of the role which the quality of HE institutions play in social 
and economic development of the country, and also to find out mechanisms for motivating the institutions' employees, so that quality becomes a priority, but not a legal obligation.

\section{References}

Ballantyne, D. (1990). Turning the Wheel of Quality Improvement - Continuously. International Journal of Bank Marketing, 8(2), 3-11. doi:10.1108/02652329010138233

Bechmann, G., Decker, M., Fiedeler, U., \& Krings, B.J. (2007). Technology assessment in a complex world. International Journal of Foresight and Innovation Policy, 3(1), 6-27. doi:10.1504/ijfip.2007.011419

Beckmerhagen, I.A., Berg, H.P., Karapetrovic, S.V., \& Willborn, W.O. (2003). Integration of management systems: focus on safety in the nuclear industry. International Journal of Quality \& Reliability Management, 20(2), 210-228. doi:10.1108/02656710310456626

Bercovitz, J., \& Feldman, M. (2006). Entpreprenerial Universities and Technology Transfer: A Conceptual Framework for Understanding Knowledge-Based Economic Development. Journal of Technology Transfer, 31(1), 175-188. doi:10.1007/s10961-005-5029-z

Borders, L.D. (1992). "Aces business", Counselor Ed and Supervision. Counselor Education and Supervision, 31(3), 184-192. doi:10.1002/j.15566978.1992.tb00160.x

Branković, J. (2013). Country Report: Montenegro. In Overview of Higher Education and Research Systems in the Western Balkans. Norwegian Research Council. Retrieved from http://www.herdata.org/public/HE and Research in Montenegro FINAL1.pdf

Branković, J., \& Branković, N. (2013). Country Report: Bosnia and Herzegovina. In Overview of Higher Education and Research Systems in the Western Balkans. $\begin{array}{llll}\text { Norwegian Research Council. Retrieved from } & \end{array}$ http://www.herdata.org/public/HE and Research in BiH FINAL.pdf

Carlucci, D., Marr, B., \& Schiuma, G. (2004). The knowledge value chain: how intellectual capital impacts on business performance. International Journal of Technology Management, 27(6/7), 575-590. doi:10.1504/ijtm.2004.004903

Comondore, V.R., Devereaux, P.J., Zhou, Q., Stone, S.B., Busse, J.W., Ravindran, N.C., \& et al., (2009). Quality of care in for-profit and not-for-profit nursing homes: systematic review and meta-analysis. BMJ: British Medical Journal, 339, 381-384

Cvijanović, J., Žižović, M., \& Lazić, J. (2007). Bologna declaration and universities management. Industrija, 35(1), 113-120.

David, M.F., \& Abreu, R.M. (2007). Proceso de Bolonia: el nuevo paradigma de la enseñanza superior. In J. Carlos \& A. Calvo (Eds.), Conocimiento, innovación y emprendedores: Camino al future Spain. (pp. 113-126). Logroño: Universidad de La Rioja.

Dobbins, M., \& Knill, C. (2009). Higher Education Policies in Central and Eastern Europe: Convergence toward a Common Model. Governance, 22(3), 397-430. doi:10.1111/j.1468-0491.2009.01445.x 
Dobbins, M., Knill, C., \& Vögtle, E.M. (2011). An analytical framework for the crosscountry comparison of higher education governance. Higher Education, 62(5), 665-683. doi:10.1007/s10734-011-9412-4

Gotzamani, K. (2004). A thorough analysis of ISO 9000 contribution to small and medium size enterprises: a comparison with large enterprises. International Journal of Management Practice, 1(1), 41-56. doi:10.1504/IJMP.2004.004869

Harman, G., \& Meek, V.L. (2000). Repositioning Quality Assurance and Accreditation in Australian Higher Education: Quality assurance and accreditation. Retrieved from http://asiapacific-odl2.oum.edu.my/C09/F409.pdf

Huet, I., Rafael, J., Costa, N., Fiqueiredo, C., \& Oliveira, J.M. (2011). Linking educational research to institutional measures of quality enhancement: a Portuguese project. In: Proceedings from ISQM2011 The 3rd International Conference of Institutional Strategic Quality Management, Romania, Sibiu, Romania, Sibiu. Retrieved from http://ria.ua.pt

Karapetrovic, S., Rajamani, D., \& Willborn, W. (1998). ISO 9001 quality system: an interpretation for the university. International Journal of Engineering Education, 14(2), 105-118

Khanifar, H., Esfidani, M.R., Nazari, H., \& Naderi, J. (2013). Evaluation of Tarbiat Modares University brand based on University Brand Ecosystem Models. International Journal of Academic Research in Business and Social Sciences, 3(7), 628-642. doi:10.6007/ijarbss/v3-i7/91

Komazec, G., Zivaljevic, A., \& Trifunovic, D. (2012). Does the economy set up request for certain educational profile. In J. Zubovic \& I. Domazet (Eds.), New Challenges in Changing Labor Markets, Serbia. (pp. 259-277). Belgrade:: Institute of Economics Sciences. Monograph Study.

Kostal, P., \& Velisek, K. (2010). Flexible manufacturing system. World Academy of Science, Engineering and Technology, 53, 825-829.

Krstić, B., \& Stanišić, T. (2013). The influence of knowledge economy development on competitiveness of southeastern Europe countries. Industrija, 41(2), 151-167. doi:10.5937/industrija41-4000

Lynch, K. (2006). Neo-liberalism and Marketisation: the implications for higher education. European Educational Research Journal, 5(1), 1-17. doi:10.2304/eerj.2006.5.1.1

Mok, K. (2003). Globalisation and Higher Education Restructuring in Hong Kong, Taiwan and Mainland China. Higher Education Research \& Development, 22(2), 117-129. doi:10.1080/07294360304111

Oppermann, M., Sauer, W., \& Wohlrabe, H. (2003). Optimization of quality costs. Robotics and Computer-Integrated Manufacturing, 19(1-2), 135-140. doi:10.1016/s0736-5845(02)00070-4

Pekić, Q.S., Pavlović, D., \& Spasić, S. (2013). "Rezultati komisije u procesu obezbeđenja kvaliteta", V. Vujičić. In Izveštaj o samovrednovanju Komisije za akreditaciju i proveru kvaliteta. (pp. 42-50). Niš, Srbija: Univerzitet u Nišu. Retrieved from http://www.kapk.org/images/stories/CAQA_SER_SRPSKI.pdf

Petković, M., Živaljević, A., \& Bagarić, I. (2005). Analiza, merenje i unapređivanje poslovnih procesa u visoko obrazovnim institucijama. Strategijski menadžment, 10(3), 138-141.

Quinn, A., Lemay, G., Larsen, P., \& Johnson, D.M. (2009). Service quality in higher education. Total Quality Management \& Business Excellence, 20(2), 139-152. doi:10.1080/14783360802622805 
Shaw, C., Groene, O., Mora, N., \& Sunol, R. (2010). Accreditation and ISO certification: do they explain differences in quality management in European hospitals. International Journal for Quality in Health Care, 22(6), 445-51. pmid:20935006. doi:10.1093/intqhc/mzq054

Sokovic, M., Pavletic, D., \& Pipan, K.K. (2010). Quality improvement methodologies PDCA cycle, RADAR matrix, DMAIC and DFSS. Journal of Achievements in Materials and Manufacturing Engineering, 42(1), 476-483.

Šćukanec, N. (2013). Country Report: Croatia. In Overview of Higher Education and Research Systems in the Western Balkans. Norwegian Research Council. Retrieved

from http://www.herdata.org/public/HE and Research in Croatia FINAL.pdf

Tin, P.B., Ismail, R., Othman, N., \& Sulaiman, N. (2012). Globalization and the factors influencing households' demand for higher education in Malaysia. International Journal of Education and Information Technologies, 6(3), 269-278. Retrieved from http://naun.org/multimedia/NAUN/educationinformation/17-649.pdf

Urošević, S., Cvijanović, J., \& Djordjević, D. (2008). Improvement of education level for employees in textile industry. Industrija, 36(3), 79-105.

Veiga, A. \& Amaral, A. (2012). The Impacts of Bologna and of the Lisbon Agenda. In Higher Education in Portugal 1974-2009, Springer, Netherlands, pp. 265-284.

Vujačić, I., Đorđević, S., Kovačević, M., \& Šunderić, I. (2013). Country Report: Macedonia. In Overview of Higher Education and Research Systems in the Western Balkans. Norwegian Research Council. Retrieved from http://www.herdata.org/public/HE and Research in Macedonia FINAL.pdf

Vujačić, I., Đorđević, S., Kovačević, M., \& Šunderić, I. (2013). Country Report: Serbia. In Overview of Higher Education and Research Systems in the Western Balkans. Norwegian Research Council. Retrieved from http://www.herdata.org/public/HE and Research in Serbia FINAL - 2.pdf

Xhaferri, E. \& Branković, J. (2013), "Overview of higher education and research systems in the Western Balkans. Albania", Project Report of Project Number 203340: "European Integration of Higher Education and Research in the Western Balkans". Norwegian Research Council, available at: http://www.herdata.org/public/HE and Research in Albania FINAL1.pdf (accessed 18 January 2014).

Živaljević, A., Mitrović, Ž., \& Petković, M. (2013). Conceptual and mathematical model for quality improvement in health care. The Service Industries Journal, 33(5), 516-541. doi:10.1080/02642069.2011.622368 